\title{
Equine Yolk Sac: A Stem Cells Source
}

\author{
Saco Vitelino Equino: Una Fuente de Células Madre
}

\begin{abstract}
André Luis R. Franciolli'; Rodrigo S. N. Barreto ${ }^{1}$; Gustavo de Sá Schiavo Matias ${ }^{1}$; Rafael C. Carvalho² ${ }^{2}$ Marcio N. Rodrigues ${ }^{1}$; Paula Fratini $^{1}$; Graciela C. Pignatari ${ }^{1}$; Sandra M. E. F. Rechsteiner ${ }^{3}$; Andrea Maria Mess ${ }^{1}$ \& Maria Angelica Miglino ${ }^{1}$
\end{abstract}

\begin{abstract}
FRANCIOLLI, A. L. R.; BARRETO, R. S. N.; MATIAS, G. S. S.; CARVALHO, R. C.; RODRIGUES, M. N.; FRATINI, P.; PIGNATARI, G. C.; RECHSTEINER, S. M. E. F.; MESS, A. M. \& MIGLINO, M. A. Equine Yolk sac: a stem cells source. Int. J. Morphol., 38(5):1412-1420, 2020.
\end{abstract}

SUMMARY: Mesenchymal stem cells are characterized by in vitro high proliferation and multilineage potential maintenance. This study aimed to isolate and characterize equine YS mesenchymal stem cells and compare these with amniotic membranes. The yolk sac (YS) and amniotic membranes (AM) were obtained from 20 pregnant mares with gestational age around 30 days. Cells were cultured in $\alpha$-MEM supplemented with $15 \%$ FBS, $1 \%$ antibiotic solution, $1 \%$ L-glutamine and $1 \%$ nonessential amino acids. To cell characterization we used cytogenetic analysis, fibroblast colony-forming unit assays, cell growth curves, immunophenotyping, flow cytometry, differentiation assays and teratoma formation. Results: Both cell sources presented fibroblastoid and epithelioid-like format. The YS cells have lower colony formation potential then AM ones, 3 versus 8 colonies per $10^{3}$ plated cells. However, YS cells grew progressively while AM cells showed steady. Both, the YS and amnion cells immunolabeled for Oct-4, Nanog, SSEA-3, cytokeratin 18, PCNA, and vimentin. In addition, presented mesenchymal, hematopoietic, endothelial and pluripotency markers in flow cytometry. Discussion: Both cell sources presented high plasticity and differed into osteogenic, adipogenic, and chondrogenic lineages, and no tumor formation in nude mice was observed. The results suggest that horse YS may be useful for cell therapy such as amnion-derived cells.

KEY WORDS: Horse; Mesenchymal stem cells; Placental stem cells; Regenerative medicine; Extraembryonic membranes.

\section{INTRODUCTION}

Stem cells are present from preimplantation until adulthood, and they possess three major characteristics: a) self-renewal: generate at least one daughter cell similar to the mother cell; b) plasticity: the ability to differentiate into multiple cell lineages; and c) ability to reconstitute functionally in vivo an injured tissue. Also, can be classified by their differentiation potential as: 1) totipotent, can differentiate in all cellular lineages; 2) pluripotent, can differentiate in almost all cellular lineages from inner cell mass; 3) multipotent, differentiate only into two of the three germ layers cells (Carlin et al., 2006).

It is noteworthy that among the new veterinary areas the regenerative medicine has expanded greatly in recent years, with increasing interest in several sources of stem cells for each specific treatment (Schnabel et al., 2013). Stem cells with more restricted differentiation potential have been isolated mostly from postnatal tissues, including bone marrow (Kucia et al., 2006), placental tissue (Yen et al., 2005) and
AM fluid (Tsai et al., 2004). However, also fetal membranes such as the YS have currently shown to be adequate sources for multipotent stem cells (Wenceslau et al., 2011)

In tissue regeneration is more efficient if it is used an induced differentiated mesenchymal progenitor cells than a natural committed progenitor cell (e.g., bone and cartilage). In 2005, the Committee of Mesenchymal Stem Cells (MSC) and Tissue International Society for Cellular Therapy (ISCT) defined by the following: MSC is adherent in culture; express CD105, CD73 and CD90 and do not express CD45, CD34, CD14 and CD1b, CD79a or CD19 and HLA-DR; and differentiate in vitro into osteoblasts, adipocytes and chondroblasts (Dominici et al., 2006).

Although bone marrow (BM) MSCs represent the most widely investigated cells for application in veterinary regenerative medicine to date, these cells have a more limited potential than embryonic stem cells in terms of both in vitro

\footnotetext{
${ }^{1}$ Department of Surgery, School of Veterinary Medicine and Animal Sciences, University of Sao Paulo, Sao Paulo, Brazil.

${ }^{2}$ Center for Agricultural and Environmental Sciences, Federal University of Maranhao, Chapadinha, Maranhao, Brazil.

${ }^{3}$ Department of Morphology, Federal University of Pelotas, Pelotas, Rio Grande do Sul, Brazil.
} 
FRANCIOLLI, A. L. R.; BARRETO, R. S. N.; MATIAS, G. S. S.; CARVALHO, R. C.; RODRIGUES, M. N.; FRATINI, P.; PIGNATARI, G. C.; RECHSTEINER, S. M. E. F.; MESS, A. M. \& MIGLINO, M. A. Equine Yolk sac: a stem cells source. Int. J. Morphol., 38(5):1412-1420, 2020.

proliferation ability and target differentiation capacity (Guest et al., 2010).

In horses, adult stem cells (ASC) are the most common type used for cell therapy, i.e. for arthritis, tendon lesion, and suspensory ligament rupture. Due to the lack in equine fetal membranes derived MSC, we aimed to isolate and characterize equine YS mesenchymal stem cells and compare to AM's, that could be alternative source for cell therapy, eliminating limitations of ASC.

\section{MATERIAL AND METHOD}

Embryonic age and cell culture. These experiments were approved by School of Veterinary Medicine and Animal Science Ethic Committee of São Paulo University (Protocol number 1475/2008). YS and amnion samples were obtained from 20 mares (30 days of pregnancy). The gestational age was standardized according to our group Franciolli et al. (2011). The YS and AM membrane tissues were plated in $35-\mathrm{mm}$ petri dishes (Corning) with $\alpha$-Minimum essential medium supplemented with $15 \%$ FBS and $1 \%$ antibiotic solution (penicillin-streptomycin), $1 \%$ L-glutamine and 1 $\%$ nonessential amino acids and incubated at $37{ }^{\circ} \mathrm{C}$. At $80 \%$ of confluence, cells were harvested with $0.25 \%$ trypsin solution (all solutions by Invitrogen) and replaced in $75 \mathrm{~cm}^{2}$ flasks.

Cytogenetic analysis. Karyotype analyses were carried out according to the standard cytogenetic protocol (Hussein et al., 2011). Briefly, YS and AM derived cells were incubated with ethidium bromide for $3 \mathrm{~h}(1.5-3 \mathrm{mg} / \mathrm{ml})$ (Invitrogen) and colcemide (Sigma) for $1.5 \mathrm{~h}(0.02-0.1 \mathrm{mg} / \mathrm{ml})$. Then, they were harvested, washed twice in phosphate-buffered saline (PBS), and incubated in $0.075 \mathrm{M} \mathrm{KCl}$ for $30 \mathrm{~min}$ at $37^{\circ} \mathrm{C}$. Following, YS and AM membrane cells were fixed in glacial acetic acid and methanol (1:3) at $4{ }^{\circ} \mathrm{C}$. G-banding was performed using routine Giemsa staining (Sigma). For each cell type, 50 metaphases were analyzed to determine the diploid chromosome number. The images were captured under Zeiss II microscope.

Fibroblast colony-forming unit (f-CFU) assay. The f-CFU assay was adapted Tondreau et al. (2004). A total of 1x103 YS or AM derived cells were plated in 90-mm Petri dishes (Corning) and culture medium was changed every 2-3 days. After 10 days the adherent cells were fixed in PFA $4 \%$ (paraformaldehyde) for $5 \mathrm{~min}$ and stained for $30 \mathrm{~min}$ using crystal violet (Sigma). Only clones composed of more than 50 cells were considered for quantification. All experimental procedures were performed in triplicate.
Assessment of cell growth: growth curve. The growth curve was daily evaluated, periodically with an interval of 24 hours between each replacing cell, from the initial chime with the following calculation: total number of cells, multiplied by $10^{4}$, multiplied by the volume of medium suspended and divided by the number of squares counted (Neubauer chamber). Followed by cell counts estimated also were transferred to the bottles 3 following the rule to obtain $\mathrm{X}$ number of cells: total number of cells $\mathrm{x} 10^{5}$ stands for the volume of resuspension medium, while it is desired number of cells for $\mathrm{X}$.

Immunophenotyping. The YS and AM derived cells were grown on coverslips in basal culture medium. After $48 \mathrm{~h}$, the cells were washed twice in tris-buffered saline (TBS, 20 $\mathrm{mM}$ Tris, $0.15 \mathrm{M} \mathrm{NaCl}$, and $0.5 \%$ Tween-20) and fixed for $24 \mathrm{~h}$ in PFA $4 \%$ after permeabilization with $0.1 \%$ Triton $\mathrm{X}$ 100 (Sigma). After blocking with $5 \%$ bovine serum albumin, cells were incubated for $1 \mathrm{~h}$ at room temperature with primary antibodies diluted in $0.5 \%$ bovine serum albumin. Primary antibodies used for immunophenotypic profile were as follows: anti-mouse oct-3/4, anti-mouse Nanog, anticytokeratin peptide 18 , anti-mouse vimentin, anti-mouse PCNA3 (all from Santa Cruz Biotechnology) e anti-mouse SSEA-3 (Millipore). After washing the antibodies thrice in TBS, fluorescein isothiocyanate conjugated antibody was added, and the antibodies were incubated for $40 \mathrm{~min}$ at room temperature. The secondary antibodies were used as follows: anti-mouse IgG and anti-goat IgG (all from Santa Cruz Biotechnology). Microscope slides were mounted in Vectashield mounting medium with or without 40.6diamidino-2-phenylindol (DAPI). Digital images were acquired with a cooled CCD camera (PCO, VC44) and processed using the ISIS software (MetaSystem).

Flow cytometry. Flow cytometry was performed using 106 cells from YS and AM membrane. Primary antibodies used were as follows: anti-human CD34, CD45 (all from R\&D Systems), anti-mouse CD105, Stro-1, Oct3/4 e Nanog (all from Santa Cruz Biotechnology). Cells were incubated with primary antibody for two hours at $4{ }^{\circ} \mathrm{C}$ followed by addition of secondary FITC-conjugated antibody (anti-mouse IgGFITC) in the dark. Flow-cytometric analysis was performed on BD FACSCalibur using the WinMdi2.8 program for analysis.

\section{Osteogenic, adipogenic, and chondrogenic differentiation} assays. All differentiation assays were performed in triplicate. To promote osteogenic differentiation, 1x104 cells were plated in six well plates in culture basal medium. After $24 \mathrm{~h}$, the medium was changed, and osteogenic medium composed of Dulbecco's modified Eagles's medium (DMEM)-low glucose (LG), $2 \%$ fetal bovine serum (FBS), 
FRANCIOLLI, A. L. R.; BARRETO, R. S. N.; MATIAS, G. S. S.; CARVALHO, R. C.; RODRIGUES, M. N.; FRATINI, P.; PIGNATARI, G. C.; RECHSTEINER, S. M. E. F.; MESS, A. M. \& MIGLINO, M. A. Equine Yolk sac: a stem cells source. Int. J. Morphol., 38(5):1412-1420, 2020.

$50 \mathrm{mM}$ ascorbate-2-phosphate (Invitrogen), and $0.1 \mathrm{mM}$ dexamethasone (Sigma) was added and changed every 3 days. After 10 days, osteogenic medium was supplemented with $10 \mathrm{mMb}$-glycerolphosphate (Sigma). At day 21, cells were washed twice in PBS, fixed for $24 \mathrm{~h}$ in $4 \%$ paraformaldehyde, and stained with von Kossa reagent (Invitrogen).

Adipogenic differentiation was performed according to the protocol for horse mesenchymal stem cells (Mambelli et al., 2009). A total of $1 \times 10^{4}$ cells were plated in six-well plates. After $24 \mathrm{~h}$, adipogenic differentiation was induced by addition of DMEM-high glucose (HG) supplemented with $2 \%$ FBS, $1 \mathrm{mM}$ dexamethasone, $100 \mathrm{mM}$ indomethacin (Sigma), 0.5 mM 1-methyl-3-isobutyxanthine (Sigma), $10 \mathrm{mg} / \mathrm{mL}$ insulin, and $1 \%$ antibiotic. The medium was changed every 3 days. At day 10, differentiated cells were washed twice in PBS and fixed as just described. Sudan II (Sigma) staining was used to detect intracellular lipid accumulation.

Chondrogenic differentiation was carried out using pellet culture technique. For the preparation of each pellet, YS and AM membrane cells were trypsinized, counted, and $2 \times 10^{6}$ cells were resuspended in culture medium StemPro ${ }^{\circledR}$ Chondrogenesis Differentiation Kit (GIBCO - Invitrogen cell culture). The YS and AM membrane cells were maintained at $37{ }^{\circ} \mathrm{C}$ in a humidified atmosphere with $5 \%$ $\mathrm{CO}_{2}$, for 21 days, by changing chondrogenic culture medium every day. After that, cell aggregates were embedded in paraffin (Media-Paraplast Plus, Oxford Lab). Sections were obtained at $4 \mu \mathrm{m}$ using a Leica microtome and stained with Masson Tricomo and Picrosirius following the routine protocol (Sigma).
Teratoma formation in nude mice assays. The YS and AM membrane cells were resuspended in DPBS solution (Invitrogen) and intramuscular injected into the limbs of nude mice in the concentration of $1 \times 10^{6}$. All injections were performed under isoflurane anesthesia (Vetbrands). Teratoma formation was evaluated 8 weeks post injection.

\section{RESULTS}

Isolation and characterization of mesenchymal progenitor cells. After the first five days of cell culture, the culture medium was discarded along with the non-adherent cells. In the cultures of YS and amnion cells, we identified fibroblastoid and epithelioid-like cells. Morphologically, the cells with fibroblast appearance had elongated, fusiform and reduced cytoplasm. In contrast, cells with epithelioid appearance were large and rounded and possessed regular cytoplasmic membrane, cytoplasm large and sparse, small and circular core (Fig. 1). Karyotype analysis was performed at 6 th passage and revealed normal diploidia $(2 n=64)$ in both sources and morphology of cells (Fig. 2 A, D).

Fibroblast colony-forming unit (f-CFU) assay. Clonogenic potential of cells derived from the YS and AM membranes was evaluated using f-CFU assay. The YS cells were able to generate around 3 colonies per $10^{3}$ plated cells. The AM membrane cells had a higher colony formation frequency of about 8 colonies per $10^{3}$ plated cells (Fig. 2B, C, E, F).

Cell growth curve. The YS cells grew progressively, but not constant until the fifth passage $(\mathrm{P})$. Between P5 and P9, we
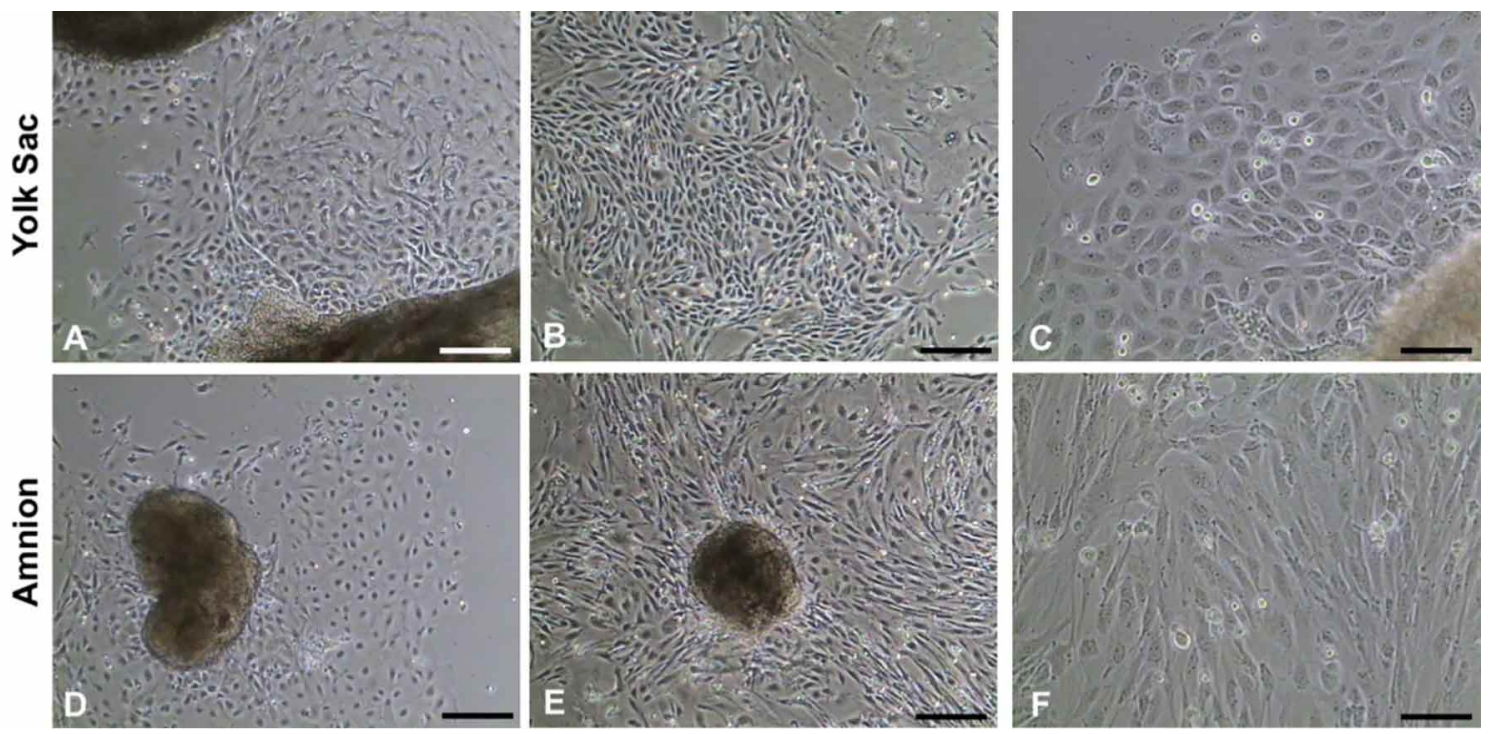

Fig. 1. Morphological changes in cells derived from yolk sac (A-C) and amnion (D-F). Note the morphologically cells with fibroblast appearance and epithelioid appearance. Scale bars: $50 \mu \mathrm{m}$. 

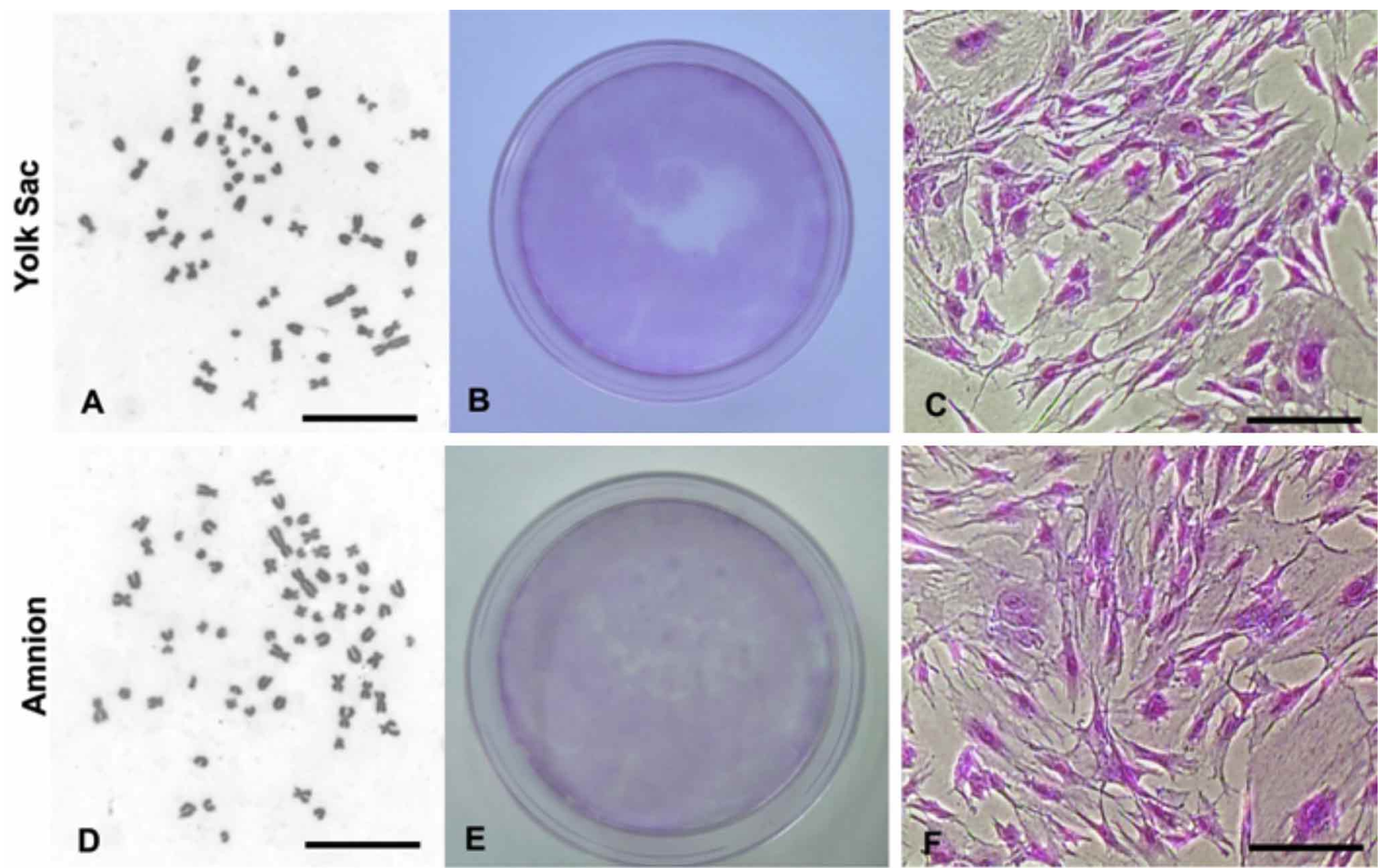

Fig. 2. Karyotype and CFU-f of cells derived from yolk sac and amnion. In A and D, equine normal karyotype (2n=64). Clonogenic efficiency of yolk sac (B-C) and amniotic (E-F) membrane cells.

observed peaks of cell growth, and a sharp decline in P10. Cells from the AM membrane showed steady, but not linear growth until the eighth passage. In P9 we observed a growth spurt, but a sharp decline occurred in P10 (Fig. 3A, B).
Flow cytometry. YS and amnion expressed markers of mesenchymal cell (CD 105 and Stro-1), hematopoietic and endothelial cells (CD 45, CD 34) as well as markers of indifferentiation (Oct3 / 4 and Nanog) (Fig. 3C, D).
Yolk Sac Cells
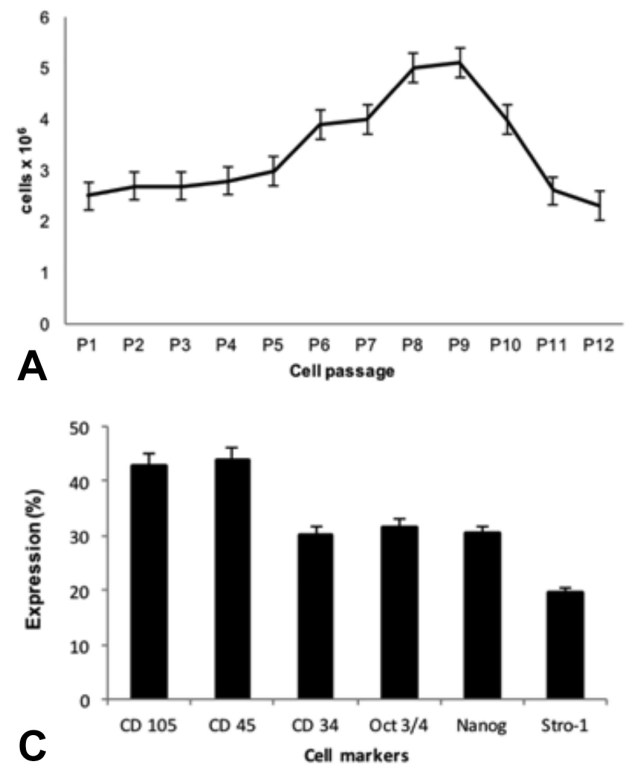

Amniotic Cell
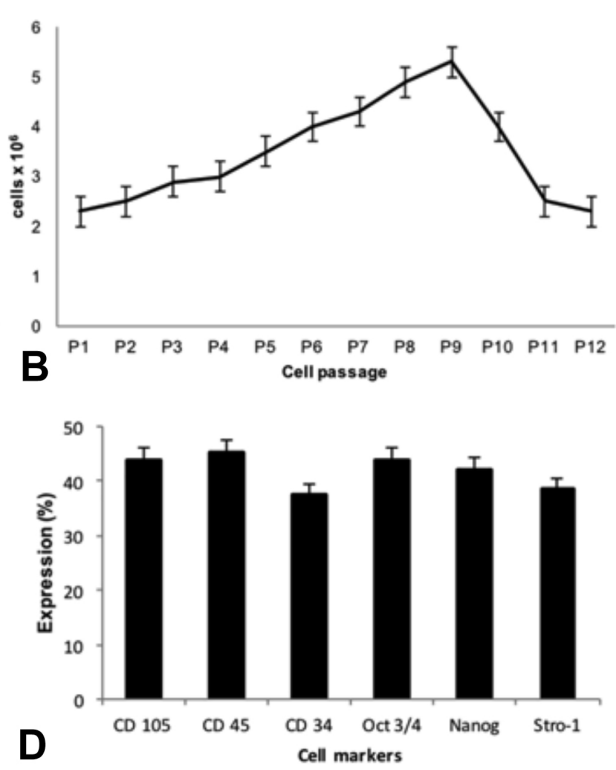

Fig. 3. Cell growth curve and cell markers expression of cells derived from yolk sac and amnion. Cell growth curve of yolk sac (A) and amnion (B) derived cells during twelve passages, indicating a decrease of cell metabolism after the ninth passage. Flow cytometry analysis in yolk sac (C) and amnion (D) derived cells of cellular markers related to mesenchymal cell (CD105 and Stro-1), hematopoietic (CD45 and CD34) and pluripotent (Oct 3/4 and Nanog) cells. 
FRANCIOLLI, A. L. R.; BARRETO, R. S. N.; MATIAS, G. S. S.; CARVALHO, R. C.; RODRIGUES, M. N.; FRATINI, P.; PIGNATARI, G. C.; RECHSTEINER, S. M. E. F.; MESS, A. M. \& MIGLINO, M. A. Equine Yolk sac: a stem cells source. Int. J. Morphol., 38(5):1412-1420, 2020.

Immunocytochemistry. In cultured YS and amnion was possible to detect some markers related to indifferentiation, such as Nanog (Fig. 4A, G), Oct-4 (Fig. 4B, H), and SSEA3 (Fig. 4D, J). Also, was possible to detect PCNA as a proliferation marker (Fig. 4E, K), and others of cytoskeleton of mesenchymal cells (vimentin) (Fig. 4F, L) and placental tissues (CK18) (Fig. 4C, I).

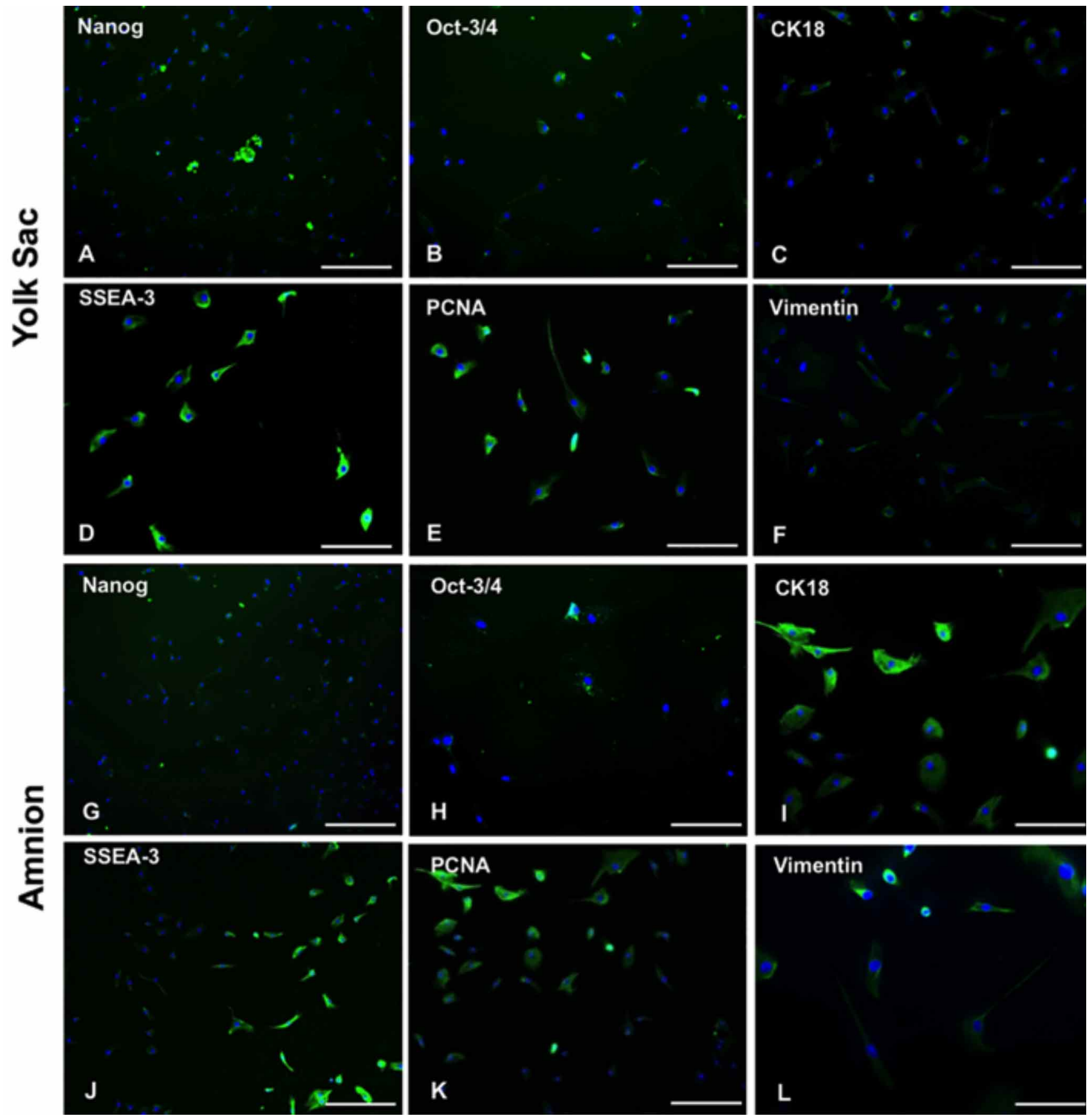

Fig. 4. Immunofluorescence in cells derived from yolk sac (A-F) and amnion (G-L). Presence of pluripotent (Nanog, OCT 3/4 and SSEA-3) and epithelial (CK18) cell markers, as well as for cell cycle (PCNA) and cytoskeleton (Vimentin).

Adipogenic, osteogenic and chondrogenic differentiation assays. From both cell sources, the osteogenic differentiation resulted in cells with polygonal morphology with cytoplasm showing locations of ossification, also bone extracellular matrix formation was evidenced by Von Kossa staining (Fig. 5A, B, E, F). In addition, adipogenic differentiation resulted 
FRANCIOLli, A. L. R.; BARRETO, R. S. N.; MATIAS, G. S. S.; CARVALHO, R. C.; RODRIGUES, M. N.; FRATINI, P.; PIGNATARI, G. C.; RECHSTEINER, S. M. E. F.; MESS, A. M. \& MIGLINO, M. A. Equine Yolk sac: a stem cells source. Int. J. Morphol., 38(5):1412-1420, 2020.

in cells with several vacuoles in their cytoplasm, as evidenced by Sudan II Scarlet stain (Fig. 5C, D, G, H). For chondrogenic differentiation, the cells evolved to rounded shape and later to isogenous groups of chondrocyte-like cells. Also, an extracellular matrix rich in collagen was produced as confirmed by Masson's trichrome (Fig. 5I, M) and picrosirius stains (Fig. 5J, L, N, P). The differentiated YS produced more collagen than AM, $37.8 \%$ and $36.4 \%$ respectively.
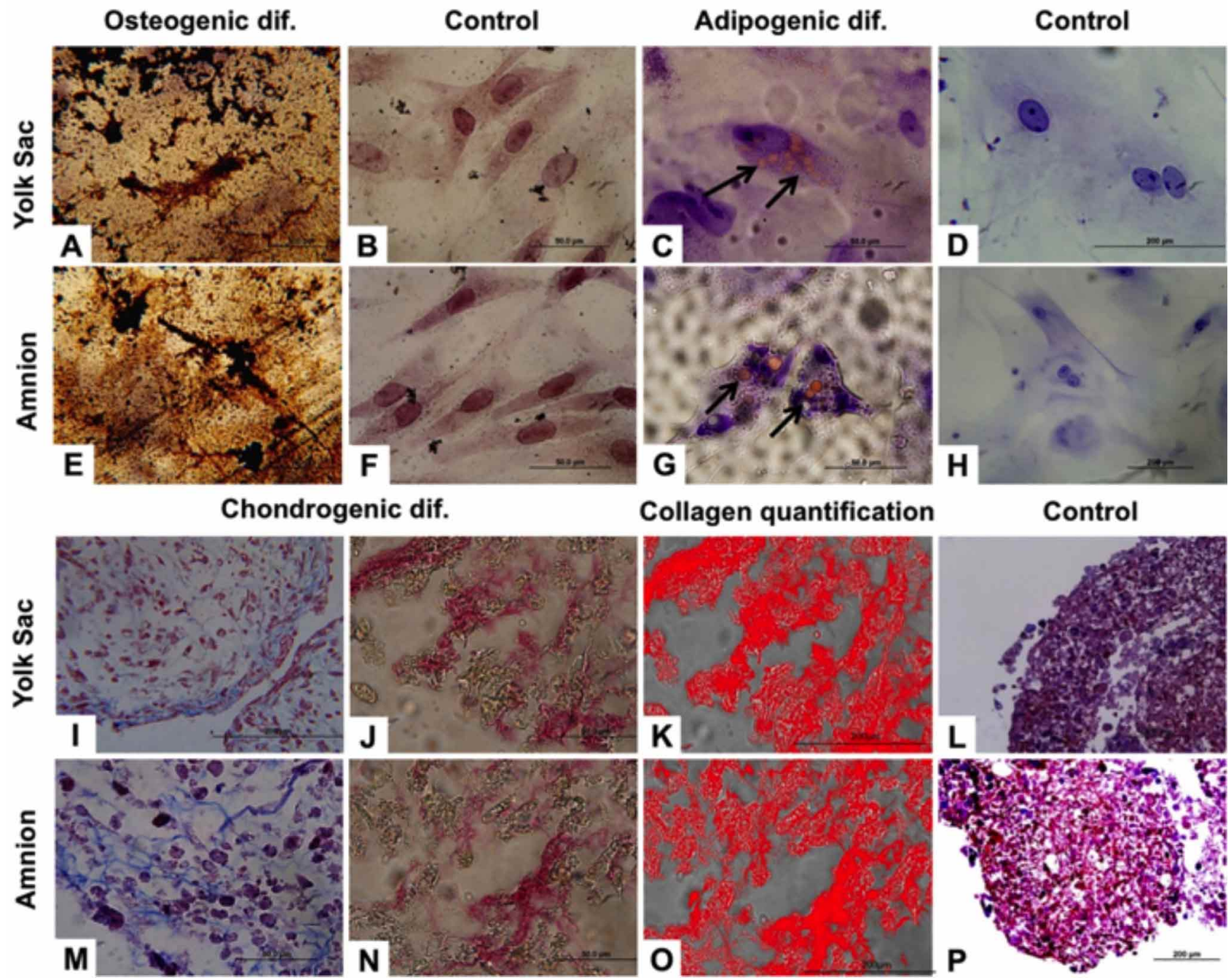

Fig. 5. Osteogenic, adipogenic and chondrogenic differentiation of cells derived from yolk sac and amnion. Yolk sac (A-B) and amnion (E-F) derived cells differentiated into osteocytes were labeled by Von Kossa staining. Yolk sac (C-D) and amnion (G-H) derived cells differentiated into adipocytes, cytoplasmic lipids granules (arrows) were evidenced by the technique of Sudan II Scarlet. Yolk sac (I-L) and amnion (M-P) derived cells differentiated into chondrocytes were visualized by Masson's trichrome (I, M) and picrosirius (J-L and $\mathrm{N}-\mathrm{P})$ stains. Areas of collagen were quantified both in yolk sac (K) and and amnion (O) derived cells.

Teratoma potential. Eight weeks after injection of YS or AM cells the nude mice were euthanized for macroscopic and microscopic evaluation. When evaluating the musculature of the left hind limb (site of cells inoculation) no neoplasic formation, disorganized tissue or cell infiltrate was observed. Also, the analyzed organs (liver, lung, kidney and heart) have no metastatic tumors, and kept their characteristic structural integrity (Fig. 6).

\section{DISCUSSION}

In the last years, AM membrane-derived cells have been largely used as a good stem cell source (Iacono et al., 2012; Violini et al., 2012). Herein, we compared the equine AM membrane derived cells from day 30 of pregnancy with YS as a different source for cell therapy. Both stem cell 

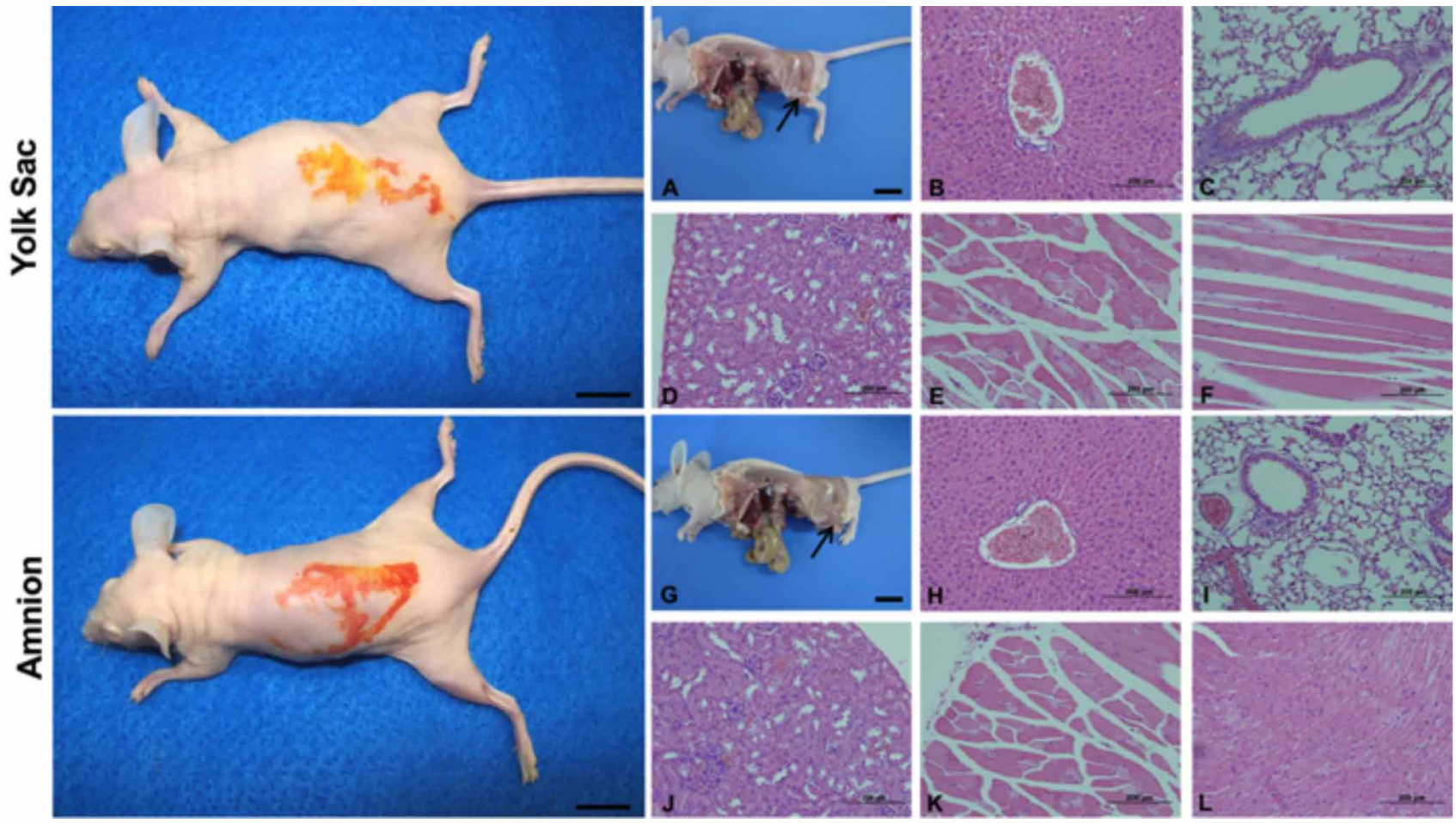

Fig. 6. Tumorigenic potential of the yolk sac (A-F) and and amnion (G-L) derived cells in immunocompromised nude mice. No alterations were found for both cells sources in hind limb inoculation (arrow, A and G), liver (B and H), lung (C and I), kidney (D and J), cardiac muscle (E and $\mathrm{K})$ and skeletal muscle (F and L).

sources showed initially fibroblastoid and epitheloid-like populations, but after fibroblastoid cells were enriched, majorly in YS culture. From both sources, the isolated cells showed capacity to colony formation, presented mesenchymal stem markers and also have capacity to differentiate to osteogenic, chodrogenic and adipogenic lineages. Mesenchymal cells in the organism are characterized by fibroblast-like morphology and also mesenchymal precursor cells of connective tissues have a stellate or spindle shape with large nuclei and high amounts of cytoplasm (Parolini et al., 2008). Cells isolated from human YS are fibroblastoid and morphologically homogeneous during several passages of cell culture (Wang et al., 2008). However, horse AM membrane culture presented more epithelioid cells then in YS culture. The presence of epithelioid cells in AM membrane culture was observe also in rats (Marcus et al., 2008), humans (Prusa \& Hengstschlager, 2002) and dogs (Vidane et al., 2014). Although cell cultures from AM membrane are more heterogenous than that derived from YS tissues, but they likewise lead to cell lineages with morphological characteristics for mesenchymal stem cells.

In addition, another characteristic of mesenchymal stem cells is the ability to form colonies when grown at low density, identified as fibroblastoid colony-forming units (CFU-f) (Caplan \& Bruder, 2001). In CFU-f assays of the human, YS and amnion progenitor cells build fibroblast colonies with more than 50 cells (Tondreau et al.), similar to our results. The ability to form CFU-f progenitor cells of YSs and amnion was more efficient than from dental pulp and bone marrow (Kuo et al., 1992). Finally, the growth curve of the cells from the horse AM membrane and YS was similar to other stem cells.

Immunocytochemistry presented immunolabelling for PCNA as proliferation marker; undifferentiated markers, i.e., Oct-4, Nanog, and SSEA -3; as well as other marker for mesenchymal stem cells, i.e., vimentin and cytokeratin 18 (CK18). This reflects various types in cell those cultures (Dazzi et al., 2006). Oct-4 and Nanog are majorly expressed in early stages of embryo development, indicating the maintenance of pluripotency and self-renewal (Carlin et al.). However, they are also expressed in some tissue-specific progenitors, i.e., dental pulp (Kerkis et al., 2006), bone marrow (Kucia et al., 2006), in fetal tissues and AM membrane (Miki et al., 2005) and umbilical funiculus (Kucia et al., 2007). Vimentin, an intermediate filament that is marker of mesenchymal origin (Ivaska et al., 2007), such as our cells. Also, CK18 is present is YS cells during epithelialmesenchymal transition (EMT) (Yagi et al., 2016). Thus, the immunolabelling of our cells suggest a that those cells are mesenchymal cells with some maintenance of indifferentiation 
and in EMT. The presence of PCNA, a nuclear protein which its synthesis is during DNA replication (G1 phase), increasing in $\mathrm{S}$ phase and decreasing in $\mathrm{G} 2$ phase (Bacchi \& Gown, $1993)$; then the presence is proportional to the cell proliferation.

By flow cytometry, YS and amnion labelled for mesenchymal (CD105, and Stro-1), hematopoietic and endothelial (CD45 and CD34) and indifferentiation (Oct3/4 and Nanog) markers, in accordance to mesenchymal stem cells derived from human YS (Wang et al.) bone marrow, umbilical funiculus and AM fluid (Lovati et al., 2011). Also, the labelling for endothelial and hematopoietic markers suggests that equine YS and amnion derived cell has a bipotential, such as previously reported for equine (Lange-Consiglio et al., 2012).

Both YS and AM derived cells had the ability to be differentiated for bone, cartilage and adipose tissues in specific inducing culture media as stated for mesenchymal stem cells (Parolini et al.). Those cells differentiated to osteogenic lineage such as cells derived from canine umbilical funiculus (Seo et al., 2009), fetal and adult bone marrow and YS (Wenceslau et al.) and equine umbilical funiculus, bone marrow and AM fluid (Lovati et al.). Furthermore, the chondrogenic differentiation was similar as for cells derived from equine adipose tissue (Raabe et al., 2010); canine umbilical funiculus (Seo et al.), bone marrow and YS (Wenceslau et al.); human YS (Wang et al.) and equine AM membrane (Wenceslau et al.). The adipogenic differentiation, was similar to observed in human bone marrow derived cells (de Lima Prata et al., 2010) and canine AM derived cells (Vidane $e$ al.), that equally do not stain well by Red Oil, but was successfully with Sudan II Scarlet. Finally, teratoma assay of the cultured cells into immunocompromised nude mice did not result in tumor formation locally, neither metastatic tumor growth in the inner organs.

\section{CONCLUSION}

Our results suggest that cells derived from YS at day 30 of pregnancy exhibit a potential to be used in cell therapy studies in horses, when compared to the largely studied AM membrane model.

ACKNOWLEDGEMENTS. This work was supported by The São Paulo Research Foundation [FAPESP, grant number 2008/54851-3] and Advanced Center of Image Diagnosis (CADI-FMVZ-USP) for supporting the microscope analyses.
FRANCIOLLI, A. L. R.; BARRETO, R. S. N.; MATIAS, G. S. S.; CARVALHO, R. C.; RODRIGUES, M. N.; FRATINI, P.; PIGNATARI, G. C.; RECHSTEINER, S. M. E. F.; MESS, A. M. \& MIGLINO, M. A. Saco vitelino equino: Una fuente de células madre. Int. J.Morphol., 38(5):1412-1420, 2020.

RESUMEN: Las células madre mesenquimales se caracterizan por una alta proliferación in vitro y un mantenimiento potencial de múltiples líneas. Este estudio tuvo como objetivo aislar y caracterizar las células madre mesenquimales del saco vitelino equinas y compararlas con las membranas amnióticas. Se obtuvo el saco vitelino (SV) y las membranas amnióticas (MA) de 20 yeguas preñadas con edad gestacional de aproximadamente 30 días. Las células se cultivaron en $\alpha$-MEM suplementado con $15 \%$ de FBS, $1 \%$ de solución antibiótica, $1 \%$ de L-glutamina y $1 \%$ de aminoácidos no esenciales. Para la caracterización celular utilizamos análisis citogenéticos, ensayos de unidades de colonias de fibroblastos, curvas de crecimiento celular, inmunofenotipaje, citometría de flujo, ensayos de diferenciación y formación de teratomas. Ambas fuentes celulares presentaron formato fibroblastoideo y epitelioide. Las células SV tienen un potencial de formación de colonias más bajo que las de MA, 3 versus 8 colonias por $10^{3}$ células en placa. Sin embargo, las células $\mathrm{SV}$ crecieron progresivamente mientras que las células MA se mostraron estables. Tanto las células YS como las células amnios están inmunomarcadas para Oct-4, Nanog, SSEA-3, citoqueratina 18, PCNA y vimentina. Además, presentó marcadores mesenquimales, hematopoyéticos, endoteliales y pluripotenciales en citometría de flujo. Ambas fuentes celulares presentaron alta plasticidad y diferían en linajes osteogénicos, adipogénicos y condrogénicos, y no se observó formación de tumores en ratones. Los resultados sugieren que el SV de caballo puede ser útil para la terapia celular, como las células derivadas de amnios.

PAlabras ClAVE: Caballo; Células madre mesenquimales; Células madre placentarias; Medicina regenerativa; Membranas extraembrionarias.

\section{REFERENCES}

Bacchi, C. E. \& Gown, A. M. Detection of cell proliferation in tissue sections. Braz. J. Med. Biol. Res., 26(7):677-87, 1993.

Caplan, A. I. \& Bruder, S. P. Mesenchymal stem cells: building blocks for molecular medicine in the 21st century. Trends Mol. Med., 7(6):25964, 2001.

Carlin, R.; Davis, D.; Weiss, M.; Schultz, B. \& Troyer, D. Expression of early transcription factors Oct-4, Sox-2 and Nanog by porcine umbilical cord (PUC) matrix cells. Reprod. Biol. Endocrinol., 4:8, 2006.

Dazzi, F.; Ramasamy, R.; Glennie, S.; Jones, S. P. \& Roberts, I. The role of mesenchymal stem cells in haemopoiesis. Blood Rev., 20(3):161-71, 2006.

de Lima Prata, K.; Orellana, M. D.; De Santis, G. C.; Kashima, S.; Fontes, A. M.; Carrara, R. C. V.; Palma, P. V. B.; Neder, L. \& Covas, D. T. Effects of high-dose chemotherapy on bone marrow multipotent mesenchymal stromal cells isolated from lymphoma patients. Exp. Hematol., 38(4):292-300.e4, 2010. 
Dominici, M.; Le Blanc, K.; Mueller, I.; Slaper-Cortenbach, I.; Marini, F. C.; Krause, D. S.; Deans, R. J.; Keating, A.; Prockop, D. J. \& Horwitz, E. M. Minimal criteria for defining multipotent mesenchymal stromal cells. The International Society for Cellular Therapy Position Statement. Cytotherapy, 8(4):315-7, 2006.

Franciolli, A. L. R.; Cordeiro, B. M.; da Fonseca, E. T.; Rodrigues, M. N.; Sarmento, C. A. P.; Ambrosio, C. E.; de Carvalho, A. F.; Miglino, M. A. \& Silva, L. A. Characteristics of the equine embryo and fetus from days 15 to 107 of pregnancy. Theriogenology, 76(5):819-32, 2011.

Guest, D. J.; Smith, M. R. W. \& Allen, W. R. Equine embryonic stem-like cells and mesenchymal stromal cells have different survival rates and migration patterns following their injection into damaged superficial digital flexor tendon. Equine Vet. J., 42(7):636-42, 2010.

Hussein, S. M.; Batada, N. N.; Vuoristo, S.; Ching, R. W.; Autio, R.; Närvä, E.; Ng, S.; Sourour, M.; Hämäläinen, R.; Olsson, C.; et al. Copy number variation and selection during reprogramming to pluripotency. Nature, 471(7336):58-62, 2011.

Iacono, E.; Brunori, L.; Pirrone, A.; Pagliaro, P. P.; Ricci, F.; Tazzari, P. L. \& Merlo, B. Isolation, characterization and differentiation of mesenchymal stem cells from amniotic fluid, umbilical cord blood and Wharton's jelly in the horse. Reproduction, 143(4):455-68, 2012.

Ivaska, J.; Pallari, H. M.; Nevo, J. \& Eriksson, J. E. Novel functions of vimentin in cell adhesion, migration, and signaling. Exp. Cell Res., 313(10):2050-62, 2007.

Kerkis, I.; Kerkis, A.; Dozortsev, D.; Stukart-Parsons, G. C.; Massironi, S. M G.; Pereira, L. V.; Caplan, A. I. \& Cerruti, H. F. Isolation and characterization of a population of immature dental pulp stem cells expressing OCT-4 and other embryonic stem cell markers. Cells Tissues Organs, 184(3-4):105-16, 2006.

Kucia, M.; Halasa, M.; Wysoczynski, M.; Baskiewicz-Masiuk, M.; Moldenhawer, S.; Zuba-Surma, E.; Czajka, R.; Vojakowski, W.; Machalinski, B. \& Ratajczak, M. Z. Morphological and molecular characterization of novel population of CXCR4+ SSEA-4+ Oct-4+ very small embryonic-like cells purified from human cord blood: preliminary report. Leukemia, 21(2):297-303, 2007.

Kucia, M.; Reca, R.; Campbell, F. R.; Zuba-Surma, E.; Majka, M.; Ratajczak, J. \& Ratajczak, M. Z. A Population of Very Small EmbryonicLike (VSEL) CXCR4(+)SSEA-1(+)Oct-4+ stem cells identified in adult bone marrow. Leukemia, 20(5):857-69, 2006.

Kuo, M. Y.; Lan, W. H.; Lin, S. K.; Tsai, K. S. \& Hahn, L. J. Collagen gene expression in human dental pulp cell cultures. Arch. Oral Biol., 37(11):945-52, 1992.

Lange-Consiglio, A.; Corradetti, B.; Bizzaro, D.; Magatti, M.; Ressel, L.; Tassan, S.; Parolini, O. \& Cremonesi, F. Characterization and potential applications of progenitor-like cells isolated from horse amniotic membrane. J. Tissue Eng. Regen. Med., 6(8):622-35, 2012.

Lovati, A. B.; Corradetti, B.; Lange Consiglio, A.; Recordati, C.; Bonacina, E.; Bizzaro, D. \& Cremonesi, F. Comparison of equine bone marrow, umbilical cord matrix and amniotic fluid-derived progenitor cells. Vet. Res. Commun., 35(2):103-21, 2011.

Mambelli, L. I.; Santos, E. J. C.; Frazão, P. J. R.; Chaparro, M. B.; Kerkis, A.; Zoppa, A. L. V. \& Kerkis, I. Characterization of equine adipose tissue-derived progenitor cells before and after cryopreservation. Tissue Eng. Part C Methods, 15(1):87-94, 2009.

Marcus, A. J.; Coyne, T. M.; Rauch, J.; Woodbury, D. \& Black, I. B. Isolation, characterization, and differentiation of stem cells derived from the rat amniotic membrane. Differentiation, 76(2):130-44, 2008.

Miki, T.; Lehmann, T.; Cai, H.; Stolz, D. B. \& Strom, S. C. Stem cell characteristics of amniotic epithelial cells. Stem Cells, 23(10):1549$59,2005$.

Parolini, O.; Alviano, F.; Bagnara, G. P.; Bilic, G.; Bühring, H. J.; Evangelista, M.; Hennerbichler, S.; Liu, B.; Magatti, M.; Mao, N.; et al. Concise review: isolation and characterization of cells from human term placenta: outcome of the first international workshop on placenta derived stem cells. Stem Cells, 26(2):300-11, 2008.

Prusa, A. R., \& Hengstschlager, M. Amniotic fluid cells and human stem cell research: a new connection. Med. Sci. Monit., 8(11):RA253-7, 2002.

Raabe, O.; Reich, C.; Wenisch, S.; Hild, A.; Burg-Roderfeld, M.; Siebert, H. C. \& Arnhold, S. Hydrolyzed fish collagen induced chondrogenic differentiation of equine adipose tissue-derived stromal cells. Histochem. Cell Biol., 134(6):545-54, 2010.

Schnabel, L. V.; Fortier, L. A.; Wayne Mcllwraith, C. \& Nobert, K. M. Therapeutic use of stem cells in horses: which type, how, and when? Vet. J., 197(3):570-7, 2013.

Seo, M. S.; Jeong, Y. H.; Park, J. R.; Park, S. B.; Rho, K. H.; Kim, H. S.; Yu, K. R.; Lee, S. H.; Jung, J. W.; Lee, Y. S.; et al. Isolation and characterization of canine umbilical cord blood-derived mesenchymal stem cells. J. Vet. Sci., 10(3):181-7, 2009.

Tondreau, T.; Lagneaux, L.; Dejeneffe, M.; Delforge, A.; Massy, M.; Mortier, C. \& \& Bron, D. Isolation of BM mesenchymal stem cells by plastic adhesion or negative selection: phenotype, proliferation kinetics and differentiation potential. Cytotherapy, 6(4):372-9, 2004.

Tsai, M. S.; Lee, J. L.; Chang, Y. J. \& Hwang, S. M. Isolation of human multipotent mesenchymal stem cells from second-trimester amniotic fluid using a novel two-stage culture protocol. Human Reprod., 19(6):1450-6, 2004

Vidane, A. S.; Souza, A. F.; Sampaio, R. V.; Bressan, F. F.; Pieri, N. C.; Martins, D. S.; Meirelles, F. V.; Miglino, M. A. \& Ambrósio, C. E. Cat amniotic membrane multipotent cells are nontumorigenic and are safe for use in cell transplantation. Stem Cells Cloning, 7:71-8, 2014.

Violini, S.; Gorni, C.; Pisani, L. F.; Ramelli, P.; Caniatti, M. \& Mariani, P. Isolation and differentiation potential of an equine amnion-derived stromal cell line. Cytotechnology, 64(1):1-7, 2012.

Wang, Y.; Xu, H.; Li, J.; Wan, H. \& Jin, S. The expression of BMP4 during the hematopoiesis of human yolk sac. Cell Res., 18:S50, 2008.

Wenceslau, C. V.; Miglino, M. A.; Martins, D. S.; Ambrósio, C. E.; Lizier, N. F.; Pignatari, G. C. \& Kerkis, I. Mesenchymal progenitor cells from canine fetal tissues: yolk sac, liver, and bone marrow. Tissue Eng. Part A, 17(17-18):2165-76, 2011.

Yagi, S.; Tagawa, Y. I. \& Shiojiri, N. Transdifferentiation of mouse visceral yolk sac cells into parietal yolk sac cells in vitro. Biochem. Biophys. Res. Commun., 470(4):917-23, 2016.

Yen, B. L.; Huang, H. I.; Chien, C. C.; Jui, H. Y.; Ko, B. S.; Yao, M.; Shun, C. T.; Yen, M. L.; Lee, M. C. \& Chen, Y. C. Isolation of multipotent cells from human term placenta. Stem Cells, 23(1):3-9, 2005.

\author{
Corresponding author: \\ Maria Angelica Miglino \\ Prof. Orlando Marques de Paiva 87 \\ CEP: 05508-270 \\ Cidade Universitária \\ Butantã \\ São Paulo, SP \\ BRAZIL
}

Email: miglino@usp.br

Received: 31-03-2020

Accepted: 17-05-2020 